\title{
IDENTIFIKASI TINGKAT PARTISIPASI MASYARAKAT STUDI KASUS KAMPUNG LOROTAN, KELURAHAN KOTALAMA, KOTA MALANG
}

\author{
Amandus Jong Tallo \\ Magister Perencanaan Kota dan Daerah \\ Universitas Gadjah Mada \\ Email: mandustallo@gmail.com \\ Dian Ayu Paramita \\ Jurusan Perencanaan Wilayah dan Kota \\ Institut Teknologi Nasional Malang- Jawa Timur
}

\begin{abstract}
Urban settlements in general are always experiencing rapid growth due to the space requirements for the population residence. Villages as part of the urban settlements also get the impact of the problems of urban development. Top-down system of government just make people as objects of development, so that can not reach the needs of the community. But with the bottom-up system of government, the public can determine an activity based on the needs and capabilities of its people. Therefore, the objectives of this study were (1) to identify the forms and motifs of public participation, (2) identify the capacity of community organizations, (3) identify the level of participation of society as a whole. This study used a qualitative descriptive analysis and used the case study method as a sample of 84 people in Lorotan village, Malang city. The results show that: (1) the tendency of the usual forms of participation is social, power, thoughts and wealth. For community participation motives, motives tend to be based on psychology, (2) based on the results of the analysis of the capacity of community organizations, there are three organizations that have a high capacity, namely, PKK, karang taruna and community forum, (3) the level of community participation overall in character of the study area, already showing the level of participation in the second degree participation. It is an added value in the study area are community able to achieve the highest level of participation without government interference.
\end{abstract}

Keywords: Community; Lorotan Village; Malang City; Participation.

\begin{abstract}
ABSTRAK.
Permukiman perkotaan pada umumnya mengalami pertumbuhan pesat karena kebutuhan ruang untuk tempat tinggal penduduk. Desa sebagai bagian dari permukiman perkotaan mendapatkan dampak dari masalah pembangunan perkotaan. Sistem top-down dari pemerintah hanya membuat orang sebgai objek pembagunan, sehingga tidak mencapai kebutuhan masyarakat. Dengan sistem bottom-up dari pemerintah, masyarakat dapat menentukan kegiatan berdasarkan kebutuhan dan kemampuan rakyatnya. Oleh karena itu tujuan dari penelitian ini adalah (1) mengidentifikasi bentuk dan motif partisipasi masyarakat, (2) mengidentifikasi kemampuan organisasi masyarakat, (3) mengidentifikasi
\end{abstract}


tingkat partisipasi masyarakat secara keseluruhan. Penelitian ini menggunakan analisis deskriptif kualitatif dan menggunakan metode studi kasus, dengan sampel 84 orang di Kampung Lorotan, Kota Malang. Hasil penelitian ini menunjukan bahawa: (1) kecendrungan bentuk-bentuk biasa dari partisipasi sosial, kekuasaan, pikiran dan kekayaan. Untuk motif berdasarkan hasi analisis kapasitas masyarakat ada tiga organisasi yang memiliki kapasitas tinggii yaitu PKK, Karang Tarunan dan Forum Komunitas, (3) tingkat partisipasi pada area studi berada pada derajat kedua. Ini adalah nilai tambah di lokasi penelitian yang menunjukan bahwa masyarakat mampu mencapai tingkat partisipasi tertinggi tanpa campur tangan pemerintah.

\section{Kata Kunci: Komunitas; Kampung Lorotan; Kota Malang; Partisipasi}

\section{PENGANTAR}

Permukiman perkotaan pada umumnya selalu mengalami pertumbuhan pesat dikarenakan kebutuhan ruang untuk bertempat tinggal penduduk yang beraktifitas di dalamnya. Kampung sebagai bagian dari permukiman perkotaan tentunya mendapatkan imbas dari permasalahan perkembangan kota. Banyak program dari pemerintah lokal tidak dapat memenuhi yang menjadi kebutuhan dan keinginan masyarakat. Sistem pemerintahan yang top down hanya menempatkan masyarakat sebagai obyek dalam kegiatan pembangunan. Pada pelaksanaannya saat ini, keterlibatan dan partisipasi masyarakat hanya sebagai penyampaian informasi dan penyuluhan sebuah proyek agar berjalan lancar. Akan tetapi, sistem pemerintahan yang bottom up, maka masyarakat dapat menentukan sebuah kegiatan berdasarkan kebutuhan dan kemampuan masyarakatnya. Peran pemerintah dapat memberikan bantuan sebagai jalan untuk mempercepat pelaksanaan program yang dilakukan. Untuk melakukan pembangunan yang bottom up tentunya membutuhkan wadah dalam menampung aspirasi warga. Oleh karena itu, dibutuhkan organisasi-organisasi lokal yang terbentuk dari upaya mandiri masyarakat.

Menurut Carney (2012) partisipasi memerlukan suatu organisasi sosial masyarakat. Organisasi sosial masyarakat berasal dari masyarakat setempat yang berperan memberikan penyuluhan kepada masyarakat partisipan yang berperan utama sebagai pelaku pembangunan. Jadi partisipasi masyarakat yang akan dibahas dalam penelitian ini menyangkut pembangunan fisik (sarana maupun prasarana permukiman) maupun pembangunan sosial, yakni pembentukan lembaga dan organisasi sosial yang dibuat untuk meningkatkan kesejahteraan warga.

Kampung Lorotan adalah salah satu kampung yang terletak di sempadan Sungai Brantas. Letak kampung berdekatan dengan pusat kota, sehingga banyak para pendatang yang memilih tinggal di kampung yang tergolong padat ini. Para pendatang memiliki mata pencaharian sebagai pedagang ayam, kuli angkut, PKL, dan sebagainya. Heterogenitas masyarakat tentunya sangat berpengaruh pada keguyuban warga karena kepribadian seseorang dipengaruhi oleh pekerjaan, latar belakang sosial, dan budaya daerah asal. Warga Kampung Lorotan memiliki organisasilokal, yaitu Forum Warga yang mewadahi kegiatan diskusi, proses pengambilan keputusan, dan pelaksanaan pembangunan. Salah satu contohnya, dalam penanganan masalah sampah, warga membuat kebijakan untuk melengkapi masing-masing gang dengan tong sampah agar warga tidak membuang sampah ke selokan dan sungai. Untuk pembangunan sosial kampung, dapat terlihat dari terbentuknya organisasi sosial Kafilul Yatim dan PAUD Darrul Jannah yang terselenggara melalui swadaya warga. Dengan kondisi sosial tersebut, Kampung Lorotan sampai saat ini mampu mempertahankan organisasi lokal yang cukup beragam, maka yang menjadi rumusan masalah adalah sejauhmana tingkat partisipasi masyarakat pada Kampung Lorotan Kelurahan Kota Lama. Dari latar belakang dan rumusan masalah yang ada, maka tujuan dari penelitian ini adalah (1) mengidentifikasi bentuk dan motif partisipasi masyarakat, 
(2) mengidentifikasi kapasitas organisasi masyarakat, (3) mengidentifikasi tingkat partisipasi masyarakat secara keseluruhan (individu dan kelompok).

Menurut Suparno (2006), kata permukiman mempunyai arti yang berbeda, yaitu (a) isi yang mempunyai implementasi yang menunjuk kepada manusia sebagai penghuni maupun masyarakat di lingkungan sekitarnya, dan (b) wadah yang menunjuk pada fisik hunian yang terdiri dari alam dan elemen-elemen buatan manusia. Secara harfiah, partisipasi berarti "turut berperan serta dalam suatu kegiatan", "keikutsertaan atau peran serta dalam suatu kegiatan", "peran serta aktif atau proaktif dalam suatu kegiatan" (Adi Fahrudin, 2011). Menurut Carney (2012) partisipasi memerlukan suatu organisasisosialmasyarakat.Organisasisosial masyarakat berasal dari masyarakat setempat yang berperan memberikan penyuluhan kepada masyarakat partisipan yang berperan utama sebagai pelaku pembangunan. Hal serupa juga dinyatakan oleh Gedikli (2009) bahwa dalam partisipasi, memerlukan partisipasi yang kuat dari organisasi publik/ masyarakat lokal. Partisipasi masyarakat yang akan dibahas dalam penelitian ini menyangkut pembangunan fisik (sarana maupun prasarana permukiman) maupun pembangunan sosial, yaitu pembentukan lembaga dan organisasi sosial yang dibuat untuk meningkatkan kesejahteraan warga. Dalam pelaksanaan partisipasi, tentu tidak selalu dapat berjalan sebagaimana mestinya. Ada beberapa faktor yang mempengaruhi kesuksesan dan kegagalan pembangunan partisipasi menurut Ife Setiawan dalam Ishak (2009), yaitu kapasitas organisasi (organization skills), kapasitas/ peran pemimpin lokal (community leadership), peran intermediate agencies, kondisi, dan situasi makro/ eksternal (obstacle within society). Menurut Lerner (2013:190) menjelaskan bahwa dalam proses partisipatif, seorang yang memimpin dalam proses partisipatif harus mampu menjadi fasilitator, membuat keputusan, dan membuat teknik rancangan. Jadi dalam proses partisipatif memerlukan seorang pemimpin yang mampu memberikan arahan bagi warga lain.

Hamijiyo dan iskandar dalam Pasaribu dan Simandjuntak (1986:349) merinci bentuk/ jenis partisipasi sebagai berikut: (a) partisipasi buah pikiran, (b) partisipasi tenaga, (c) partisipasi harta benda, (d) partisipasi keterampilan dan kemahiran, (e) partisipasi sosial. Untuk motif partisipasi masyarakat, Billah (1985) menyampaikan bahwa terdapat lima motif partisipasi masyarakat, yaitu (a) motif psikologi bahwa orang akan berpartisipasi untuk mencapai kepuasan pribadi, pencapaian prestasi, rasa telah mencapai sesuatu dapat merupakan motivasi yang kuat bagi seseorang untuk melakukan kegiatan, termasuk juga untuk berpartisipasi meskipun kegiatan atau partisipasinya itu tidak akan menghasilkan keuntungan, (b) motif sosial yaitu orang akan berpartisipasi di dalam suatu kegiatan jika keikutsertaanya itu akan membawa dampak meningkatnya status sosialnya. Pada sisi negatif orang akan "terpaksa" berpartisipasi dalam suatu kegiatan karena "takut" terkena sanksi sosial, (c) motif keagamaan, yaitu motif ini didasarkan pada kepercayaan dan kekuatan yang ada di luar manusia (Tuhan, sesuatu yang gaib di luar manusia, dan supernatural), (d) motif ekonomi yaitu keuntungan. Keuntungan merupakan motif ekonomi yang seringkali mendorong orang ikut berpartisipasi dalam kegiatan, (e) motif politik dengan dasar utama adalah kekuasaan. Oleh karena itu, partisipasi seseorang atau golongan akan ditentukan oleh besar-kecilnya kekuasaan yang dapat diperoleh dari partisipasinya di dalam berbagai kegiatan.

Menurut UNICEF dalam Kolopaking dan Tonny (2007) paling tidak ada 7 komponen kapasitas di tingkat komunitas yaitu: (a) community leader adalah orangorang yang berpengaruh dalam masyarakat yang dapat mendorong penguatan kelompok, (b) community technology mrupakan teknologi komunitas yang tepat guna yang dimiliki oleh suatu komunitas atau organisasi untuk menjalankan 
peranannya, (c) community fund yaitu segala bentuk dana yang dapat dihimpun dari dan oleh masyarakat, (d) community material yaitu sarana yang ada pada masyarakat yang berguna untuk pengembangan kelompok, (e) community knowledge yaitu persepsi masyarakat berakitan dengan usaha mereka, harapan terhadap pelayanan ekonomi produktif, sejauhmana kepercayaan pada pelaku pelayanan ekonomi produktif, (f) community decision making yaitu pelibatan anggota anggota komunitas dalam proses pengambilan keputusan, (g) community organizations merupakan perkumpulan orang dalam masyarakat yang mengelola kegiatan tertentu.

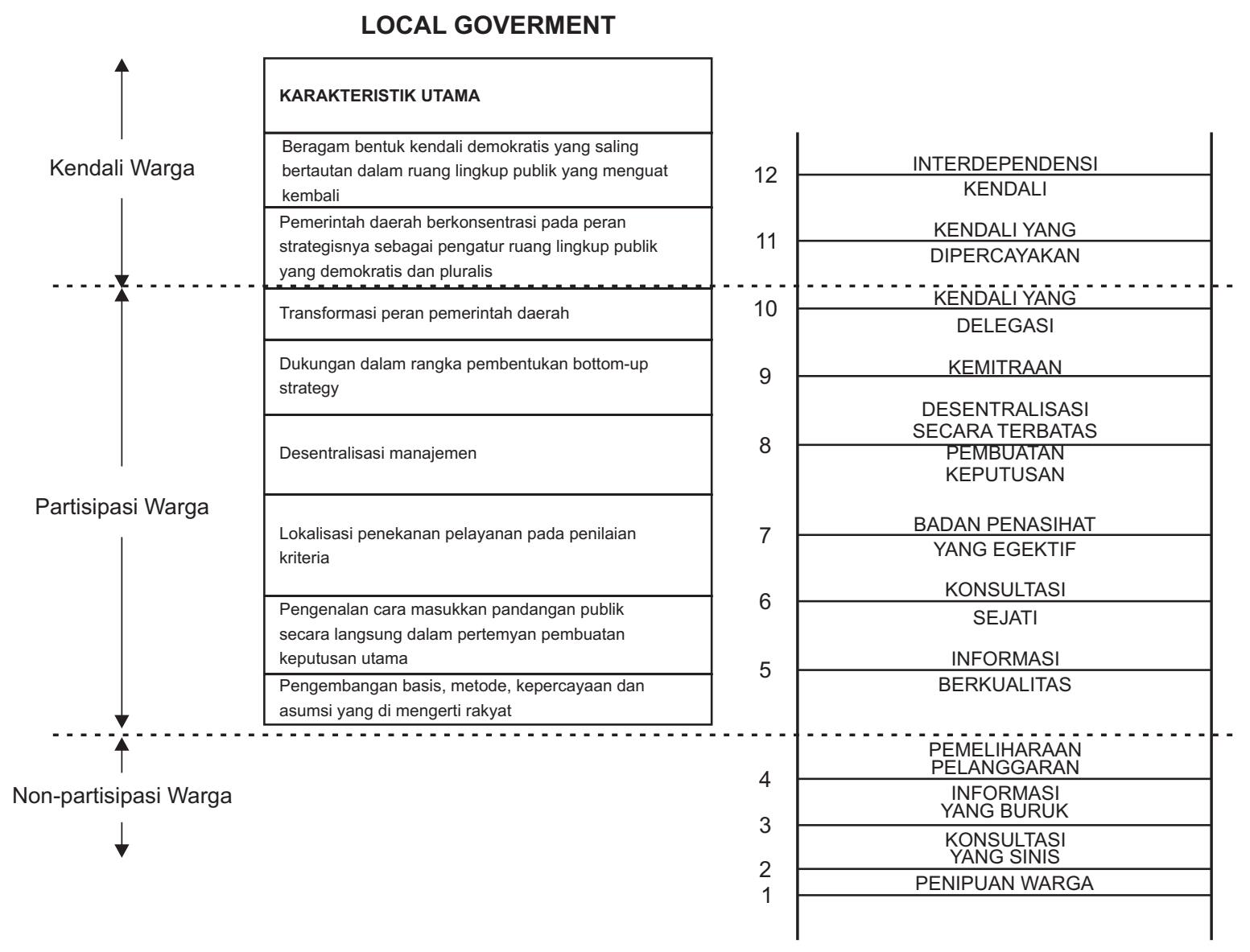

Gambar 1. Derajat Partisipasi Burns, Hambelton, dan Hogget (1994)

Penelitian ini menggunakan analisa deskriptif kualitatif dengan metode studi kasus. Bogdan dan Biklen dalam Erna (2010:35) bahwa studi kasus merupakan pengujian rinci terhadap (orang, peristiwa, atau organisasi) beserta latarnya. Sementara Yin (1989) memberikan batasan bahwa studi kasus adalah cara untuk meyelidiki fenomena kontemporer dalam konteks kehidupan nyata, khususnya jika ada ketidakjelasan bukti keterkaitan antara fenomena dengan konteks. Metode pengumpulan data dengan survey primer yaitu dan sekunder. Survey primer yaitu dengan observasi, wawancara, dan kuesioner. Kuesioner diberikan untuk responden yang dijadikan sampel. Penentuan sampel dilakukan dengan menggunakan rumus Slovin. Hasilnya dari 533 KK maka didapat 84 orang sebagai sampel. Survey sekunder dilakukan untuk membantu 
pengumpulan data pelengkap yang tidak diperoleh dalam survey primer. Data survey sekunder yang digunakan dalam penelitian ini bersumber dari buku monografi kelurahan yang memuat jumlah penduduk, jumlah KK, dan jumlah sarana serta prasarana yang diperoleh dari Kantor Kelurahan Kotalama atau dari para ketua RW. Analisa yang dilakukan yaitu dengan menggunakan tiga analisa yaitu (a) analisa bentuk dan motif partisipasi, (b) analisa kapasitas organisasi, (c) analisa tingkat partisipasi masyarakat secara keseluruhan. Dengan ketiga analisa tersebut maka kemudian dapat dilakukan penyimpulan penelitian.

\section{PEMBAHASAN}

Kampung Lorotan secara administratif merupakan wilayah dari RW 4 di Kelurahan Kotalama, yang terdiri dari 13 RT. Berdasar pada hasil observasi, luas Kampung Lorotan adalah 4,55 Ha. Pola penggunaan lahan pada kampung Lorotan didominasi oleh permukiman dan lahan yang ada sebagian besar merupakan lahan terbangun. Berikut peta batas administratif Kampung Lorotan seperti pada Gambar 2.

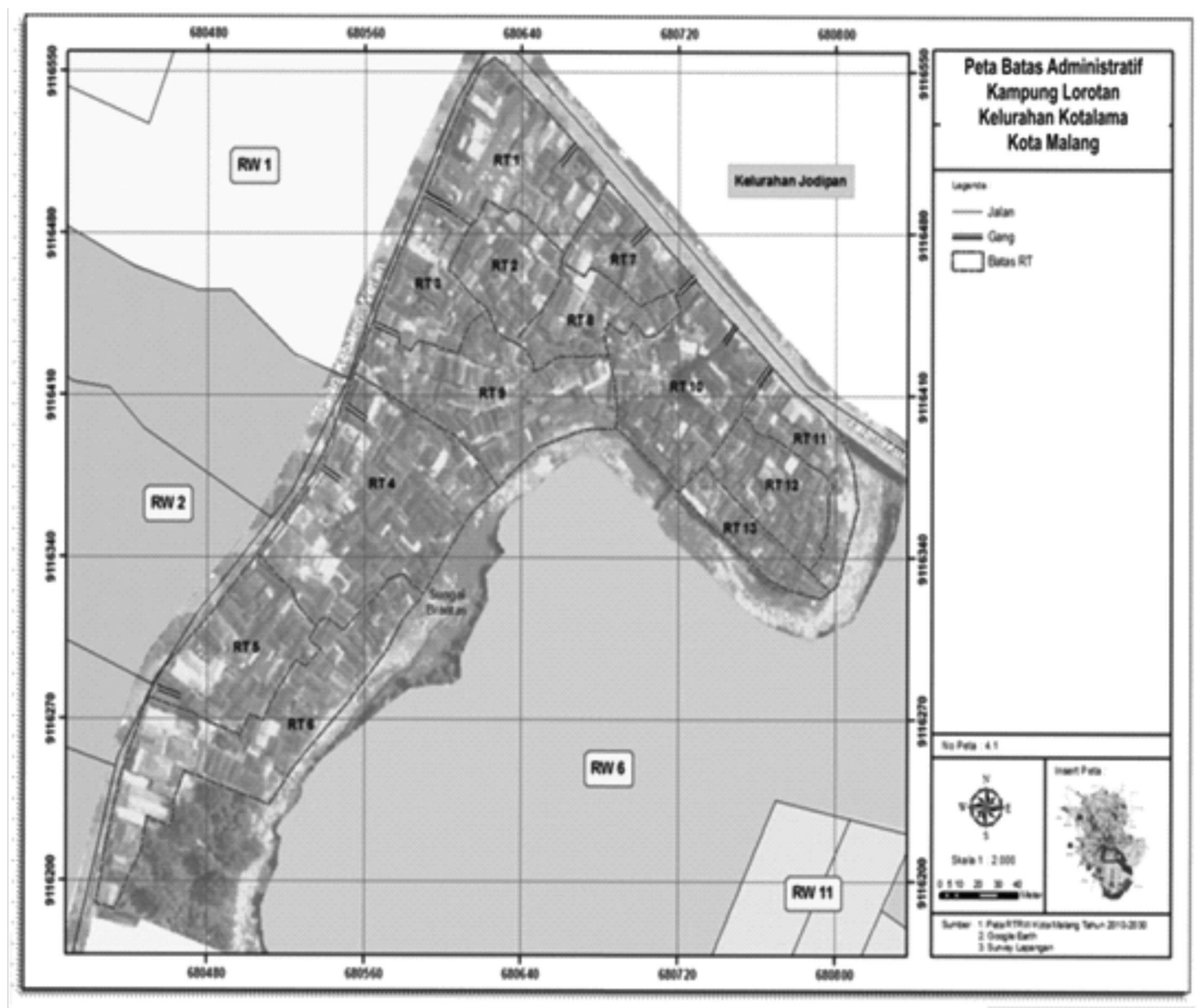

Gambar 2. Peta Batas Administratif Kampung Lorotan, Kotalama, Malang 
Dalam berpartisipasi setiap orang pasti memiliki tujuan dan motivasi yang berbedabeda, begitu juga pada bentuk partisipasi yang dilakukannya, pasti bergantung dengan kemampuan secara individu. Tujuan dari analisa bentuk dan motif warga adalah untuk mengetahui seberapa besar prosentase kecenderungan partisipasi pada tingkat perseorangan. Proses pengumpulan data untuk analisa ini dilakukan dengan menggunakan kuisioner.

\section{Analisa Bentuk dan Motif Partisipasi}

Setiap orang memiliki bentuk dan motif partisipasi yang berbeda, bergantung pada kemampuan tiap individu. Hasil analisa bentuk partisipasi yaitu bentuk partisipasi warga Kampung Lorotan berupa buah pikiran, tenaga, harta benda, dan sosial. Untuk lebih jelasnya, dapat dilihat pada Gambar 3.

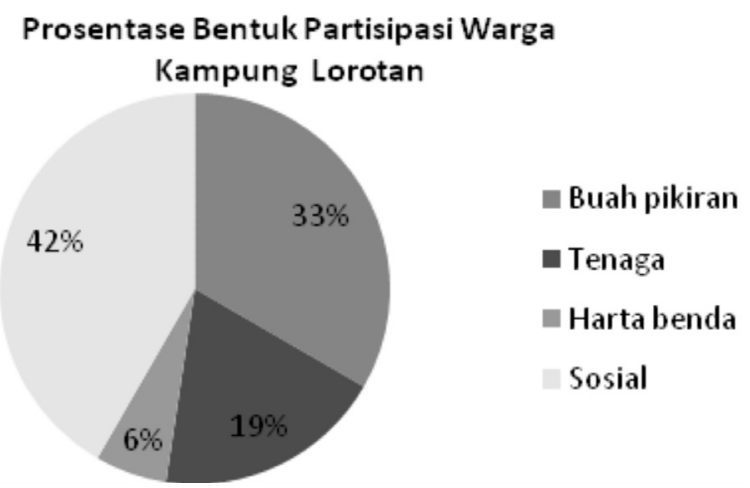

Gambar 3. Diagram Prosentase Bentuk

Partisipasi Warga Kampung Lorotan

Berdasarkan Gambar 3 dapat dianalisis bahwa partisipasi warga Kampung Lorotan lebih banyak dilakukan pada kegiatan-kegiatan yang dapat menjaga ikatan kemasyarakatan, contohnya arisan, pengajian, melayat, istigosah, dan sebagainya. Di urutan yang kedua yaitu partisipasi tenaga, biasanya dilakukan untuk mendukung pelaksanaan suatu kegiatan. Selanjutnya adalah partisipasi buah pikiran, yang dalam pelaksanaannya partisipasi tersebut dapat dilakukan dengan menghadiri pertemuan/rapat organisasi lokal yang ada melalui Forum Warga. Bentuk partisipasi yang terakhir adalah harta benda, bentuk partisipasi harta benda biasanya berupa sumbangan untuk perbaikan perkerasan semen dan santunan anak yatim serta dhuafa, dan sebagainya.

Hasil analisa motif partisipasi warga Kampung Lorotan adalah berupa motif psikologi, sosial, keagamaan, ekonomi, dan politik. Untuk motif partisipasi warga Kampung Lorotan dapat dilihat pada Gambar 4.

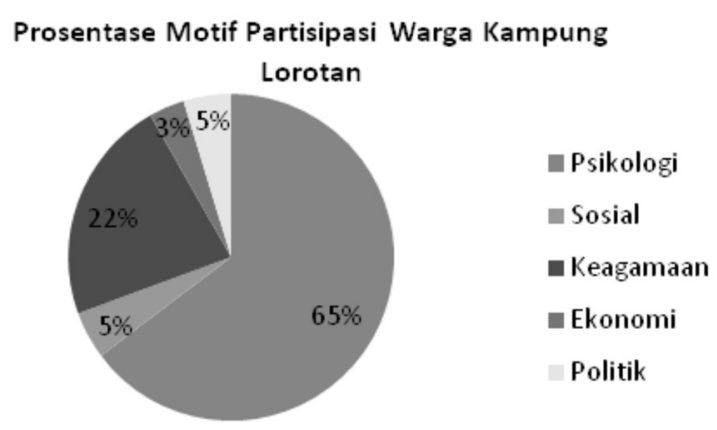

Gambar 4. Diagram Prosentase Motif Partisipasi Warga Kampung Lorotan

Berdasarkan Gambar 4 dapat dianalisis bahwa motif partisipasi didominasi oleh motif psikologi bahwa warga kampung memiliki motivasi kuat dalam melakukan kegiatan, hal tersebut lebih didorong oleh rasa kepuasan pribadi untuk menjadi lebih baik lagi melalui berbagai upaya yang telah dilakukan. Motif patisipasi yang kedua adalah motif keagamaan, hal tersebut dapat terlihat dari banyaknya warga yang aktif dalam kegiatan keagamaan dengan tujuan untuk kepuasan batin mereka sebagai makhluk yang beragama. Sedangkan yang terakhir adalah motif politik, jadi biasanya yang diharapkan dari sebuah partisipasi adalah mendapatkan kekuasaan baik secara individu atau kelompok.

\section{Analisa Kapasitas Organisasi}

Pada analisa kapasitas organisasi ini akan membandingkan antara enam organisasi lokal dengan tujuh komponen kapasitas yang harus dimiliki untuk pengembangan sebuah kelembagaan. Pada analisa ini akan 
terlihat kemampuan/kekuatan dari masingmasing organisasi, kapasitas organisasi yang paling tinggi tentunya memiliki kegunaan multifungsi dan mampu memberdayakan para anggotanya. Informan kunci yang memberikan keterangan terkait, tentunya adalah ketua/wakil dari organisasi yang ada. Perwakilan dari PKK adalah Ibu Sari (bu RW saat ini), Karang Taruna diwakili oleh ketuanya adalah Ahmad Baidowi, Forum Warga berdasarkan keterangan dari Bapak Musolli selaku koordinator, Muslimat oleh wakil organisasi adalah Ibu Ulifa, Jamaah Tahlil dengan Bapak Khoiron, dan yang terakhir Kafilul yatim dengan wakilnya adalah ibu Alfian Hutija. Untuk lebih jelas mengenai hasil observasi dapat dilihat pada Tabel 1.

Berdasarkan hasil wawancara dan observasi, ada 3 organisasi yang memiliki kapasitas paling tinggi yaitu Karang Taruna, PKK, dan Forum Warga. Untuk komponen pertama adalah community leader, pasti dimiliki oleh setiap organisasi. Hal yang menjadi nilai tambah adalah ketika organisasi tersebut memiliki leader pada satu bidang spesifik misalnya kesehatan, keterampilan, dan sebagainya (seperti yang ada pada PKK dan Karang Taruna). Untuk 4 organisasi lainnya, hanya memiliki leader umum adalah ketua/koordinator.

Tabel 1. Matrik Kapasitas Organisasi Kampung Lorotan

\begin{tabular}{|c|c|c|c|c|c|c|}
\hline $\begin{array}{l}\text { Organisasi } \\
\text { Komponen }\end{array}$ & PKK & $\begin{array}{l}\text { Karang } \\
\text { Taruna }\end{array}$ & Forum Warga & Muslimat & Tahlil & Kafilul Yatim \\
\hline $\begin{array}{l}\text { Community } \\
\text { Leader }\end{array}$ & $\begin{array}{l}{ }^{*} \text { ketua } \\
\text { organisasi } \\
\text { *kader } \\
\text { posyandu }\end{array}$ & $\begin{array}{l}{ }^{*} \text { ketua } \\
\text { organisasi } \\
{ }^{*} \text { kader } \\
\text { keterampilan }\end{array}$ & $\begin{array}{l}\text { *koordinator } \\
\text { (ketua RW) }\end{array}$ & $\begin{array}{l}{ }^{*} \text { ketua } \\
\text { organisasi }\end{array}$ & $\begin{array}{l}{ }^{*} \text { koordinator } \\
\text { kelompok } \\
\text { tahlil }\end{array}$ & $\begin{array}{l}{ }^{*} \text { ketua } \\
\text { organisasi }\end{array}$ \\
\hline $\begin{array}{l}\text { Community } \\
\text { Technology }\end{array}$ & $\begin{array}{l}\text { *arisan } \\
\text { *pelatihan } \\
\text { *penyuluhan }\end{array}$ & $\begin{array}{l}\text { *pembelajaran } \\
\text { *pelatihan }\end{array}$ & $\begin{array}{l}\text { *pertemuan } \\
\text { rutin } \\
\text { *penyuluhan } \\
\text { *pelatihan }\end{array}$ & $\begin{array}{l}\text { *kegiatan } \\
\text { santunan } \\
\text { *yatin dan } \\
\text { tahlil }\end{array}$ & *tahlil & $\begin{array}{l}\text { *pendataan } \\
\text { dan } \\
\text { pendanaan } \\
\text { *santunan dan } \\
\text { sunat massal }\end{array}$ \\
\hline $\begin{array}{l}\text { Community } \\
\text { Fund }\end{array}$ & $\begin{array}{l}\text { *arisan } \\
\text { *pelatihan } \\
\text { pembuat kue } \\
\text { *penyuluhan } \\
\text { kebersihan }\end{array}$ & $\begin{array}{l}\text { *dana donatur } \\
\text { *pelatihan } \\
\text { keterampilan } \\
\text { flanel }\end{array}$ & $\begin{array}{l}\text { *penyuluhan } \\
\text { (kebersihan, } \\
\text { keamanan, } \\
\text { dsb) }\end{array}$ & $\begin{array}{l}\text { *santunan } \\
\text { *arisan }\end{array}$ & $\begin{array}{l}\text { *dana } \\
\text { pelaksanaan } \\
\text { Kegiatan }\end{array}$ & *santunan \\
\hline $\begin{array}{l}\text { Community } \\
\text { Material }\end{array}$ & $\begin{array}{l}\text { *keterampilan } \\
\text { dan } \\
\text { pengetahuan }\end{array}$ & $\begin{array}{l}\text { *pengumpulan } \\
\text { dana donatur }\end{array}$ & $\begin{array}{l}\text { *sarana } \\
\text { administrasi } \\
\text { organisasi } \\
\text { *keterampilan } \\
\text { dan } \\
\text { pengetahuan } \\
\text { *keaktifan } \\
\text { warga }\end{array}$ & $\begin{array}{l}\text { *keguyuban } \\
\text { warga }\end{array}$ & $\begin{array}{l}{ }^{*} \text { keguyuban } \\
\text { warga }\end{array}$ & $\begin{array}{l}\text { *sarana } \\
\text { administrasi } \\
\text { organisasi } \\
\text { *pengumpulan } \\
\text { dana donatur }\end{array}$ \\
\hline $\begin{array}{l}\text { Community } \\
\text { Knowledge }\end{array}$ & $\begin{array}{l}\text { *penyuluhan } \\
\text { *pelatihan }\end{array}$ & *pelatihan & $\begin{array}{l}\text { *persepsi } \\
\text { warga } \\
\text { *penyuluhan } \\
\text { *pelatihan }\end{array}$ & - & ${ }^{*}$ ceramah & - \\
\hline $\begin{array}{l}\text { Community } \\
\text { Decision } \\
\text { Making }\end{array}$ & - & $\begin{array}{l}\text { *melibatkan } \\
\text { anggota }\end{array}$ & $\begin{array}{l}\text { *melibatkan } \\
\text { anggota }\end{array}$ & - & - & $\begin{array}{l}\text { *melibatkan } \\
\text { anggota }\end{array}$ \\
\hline $\begin{array}{l}\text { Community } \\
\text { Organi- } \\
\text { zations }\end{array}$ & - & - & - & - & - & - \\
\hline
\end{tabular}


Pada komponen yang kedua, community technology dimiliki oleh setiap organisasi baik dari sistem simpel maupun kompleks. Teknologi tentunya tidak terbatas pada alat, tetapi dapat berupa media untuk mencapai tujuan dan untuk komponen ini dimiliki oleh semua organisasi.

Pada komponen ke tiga yaitu community fund, dana yang digunakan untuk menjalin kekerabatan dapat berbentuk materi dan immaterial (dalam bentuk pengetahuan dan keterampilan teknik). Kedua bentuk dana tersebut ada pada PKK dan Karang Taruna, sedangkan organisasi lain bentuk dana yang digunakan hanya salah satu yaitu berupa materi saja/ immaterial saja. Komponen ke empat yaitu community material merupakan modal/materi pengembangan sebuah organisasi. Modal pengembangan ini tentunya dapat bervariasi, misalnya pada PKK, modal yang dimiliki untuk mengembangkan diri adalah keterampilan dan pengetahuan. Ada yang sedikit berbeda dari modal organisasi yang dimiliki oleh Karang Taruna, Forum Warga, dan Kafilul Yatim adalah sarana administrasi organisasi. Hal ini dapat terjadi sebab administrasi yang dijalankan sebuah organisasi telah dipercaya oleh warga dan manfaatnya telah dirasakan sehingga perkembangan organisasi akan lebih cepat. Untuk organisasi keagamaan (contoh:Muslimat) tidak memiliki komponen ini karena kegiatan yang dilakukan untuk peningkatan keimanan dan menjaga keguyuban warga.

Pada komponen ke lima adalah community knowledge. Biasanya kegiatan yang dilakukan untuk menambah pengetahuan melalui penyuluhan dan pelatihan. Organisasi yang memiliki kelebihan dalam komponen ini adalah Forum Warga karena setiap aspirasi dan persepsi warga ikut diperhitungkan dalam setiap pengambilan keputusan. Pada organisasi Muslimat dan Kafilul Yatim, pengetahuan anggota tidak mendapatkan perhatian, jadi organisasi tersebut hanya menjalankan program/ kegiatan yang rutin dilakukan. Komponen ke enam adalah community decision making merupakan komponen yang paling penting dalam sebuah rangkaian partisipasi. Alur/ tahap yang dimiliki dari tiap organisasi untuk membuat sebuah keputusan pasti memiliki perbedaan. Organisasi yang melibatkan anggota dalam pengambilan keputusan dan berdasar dari musyawarah adalah Karang Taruna, Forum Warga, dan Kafilul Yatim.

Pada komponen yang terakhir community organizations merupakan sebuah perkumpulan orang dalam masyarakat yang mengelola kegiatan tertentu. Organisasi tersebut biasanya adalah organisasi ekonomi produktif seperti Koperasi tani, KUD. Pada komponen ini belum ada organisasi yang memiliki kegiatan ekonomi produktif secara jelas Di Kampung Lorotan sebenarnya memililki potensi untuk mengembangkan organisasinya menjadi organisasi ekonomi produktif, yaitu PKK dan Karang Taruna. Ibu-ibu PKK dahulu pernah memiliki kegiatan mendaur ulang sampah, tetapi lemahnya kelembagaan dan distribusi akhirnya kegiatan tersebut terhenti. Berdasar pada teori yang ada di awal analisa ini maka terbukti bahwa di Kampung Lorotan memang belum memiliki unsur pendamping professional/kemitraan dalam pengembangan kegiatan organisasinya sehingga belum mampu menarik partisipasi yang lebih dari masyarakat.

\section{Analisa Tingkat Partisipasi}

Analisa tingkat partisipasi Warga Kampung Lorotan dengan menggunakan teori derajat partisipasi Burns, Hambelton, dan Hogget yaitu sebagai berikut:

a. Derajat terendah non-partisipasi warga, derajat ini ditandai dengan manipulasi informasi, dan kesan yang sering kali terjadi dalam kehidupan publik.

(1)Penipuan Warga Pada tahap ini ketua RW memiliki peran ganda, yaitu saat menyampaikan informasi dari kantor kelurahan dan juga sebagai pembuat kebijakan sebagai koordinator pada Forum Warga. 


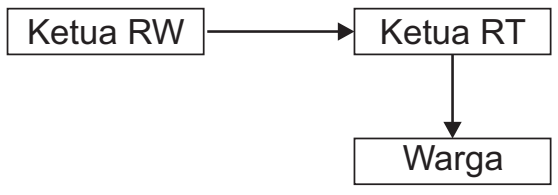

Gambar 5. Alur Penyampaian Informasi dalam Kasus Penipuan Warga

Keterangan :

Untuk mempermudah peyampaian informasi, ketua RW hanya menginformasikan pada para ketua RT

Peran Ketua RW : pemberi informasi dan pembuat kebijakan

Peran Ketua RT : mendistribusikan informasi

Peran Warga : penerima informasi

(2) Konsultasi yang Sinis

Konsultasi yang sinis tidak terjadi di lokasi penelitian sebab setiap elemen memiliki peranannya masingmasing. Jika ada keluhan dapat langsung disampaikan pada ketua RW/ RT dan juga pada pengurus organisasi yang ada.

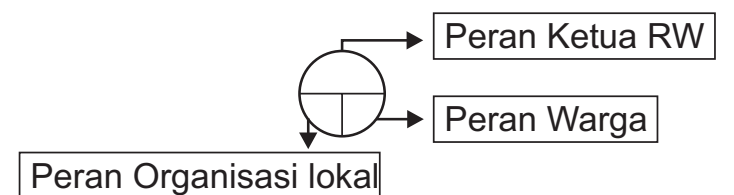

Gambar 6. Konsultasi Sinis yang Gagal

Keterangan :

Setiap elemen memiliki peran masing-masing, saling bergantung

Peran Ketua RW : pemberi informasi dan pembuat kebijakan

Peran Ketua RT : wadah partisipasi warga

Peran Warga : penerima informasi

(3) Kualitas Informasi yang Buruk

Kualitas informasi yang buruk tidak terjadi pada lokasi penelitian karena warga memiliki mekanisme penyampaian informasi yang menurut mereka paling efektif .

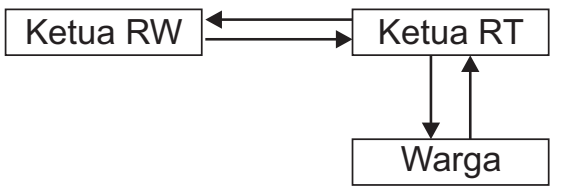

Gambar 7. Kualitas Informasi yang Buruk
Keterangan :

Alur yang demikian dianggap lebih efektif ,baik dalam peyampaian informasi maupun untuk menangapi informasi Peran Ketua RW : pemberi informasi dan penerima masukan

Peran Ketua RT : mendistribusikan informasi dan menampung masukan

Peran Warga : penerima informasi dan pemberi masukan

(4) Pemeliharaan Pelanggan

Dengan adanya Forum Warga, pemeliharaan pelanggan dapat terjaga dalam bentuk informasi mengenai bantuan, rincian dana pembangunan, dan sebagainya.

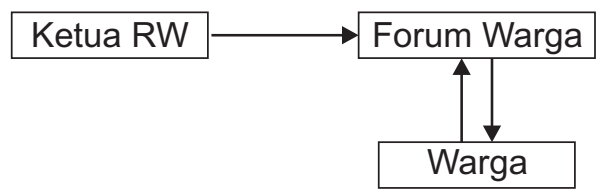

Gambar 8. Pemeliharaan Pelanggan

Keterangan :

Peran Ketua RW : koordinator pelaksanaan

Peran Ketua RT : memberi informasi mengenai dana pembangunan, raskin, sembako murah, dsb

Peran Warga : penerima informasi

b. Derajat yang kedua adalah partisipasi warga (citizen participation). Pada derajat ini partisipasi telah terjadi karena warga memiliki kuasa untuk mempengaruhi pengambilan keputusan.

(1)Informasi Berkualitas

Informasi yang berkualitas pada lokasi penelitian merupakan tanggung jawab dari masing-masing organisasi yang ada kepada anggota maupun masyarakat secara luas, jadi ketua RW hanya memantau kinerja saja.

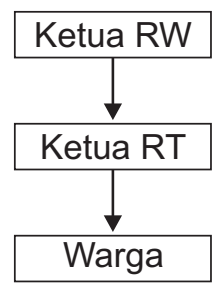

Gambar 9. Informasi Berkulitas 
Keterangan :

Peran Ketua RW : pemberi kepercayaan pada organisasi lokal

Peran Organisasi lokal : mempertanggungjawabkan segala kinerja dan perkembangan suatu program

Peran Warga rima manfaat adanya organisasi lokal

(2)Konsultasi Sejati

Wadah untuk menyalurkan aspirasi di Kampung Lorotan adalah Forum Warga, di mana dalam forum tersebut selain sebagai sarana pelatihan, memberi informasi terbaru, juga dapat sebagai tempat berdiskusi untuk penanganan permasalahan kampung.

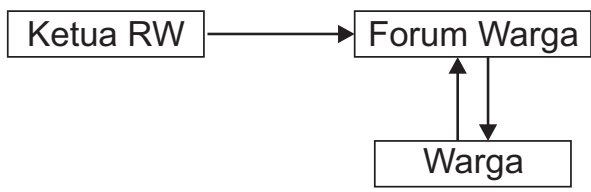

Gambar 10. Konsultasi Sejati

Keterangan :

Forum warga memiliki peran yang kompleks

Peran Ketua RW : koordinator pelaksanaan

Peran Forum warga : wadah pengambilan keputusan bersama

Peran Warga : : pihak yang menanggapi/pemberi saran

(3) Badan Penasihat yang Efektif Dengan adanya Forum Warga dapat meningkatkan partisipasi warga sebebas-bebasnya untuk perkembangan kampung yang lebih baik. Jadi forum tersebut dapat juga menjadi organisasi fasilitator bagi warga kampung.

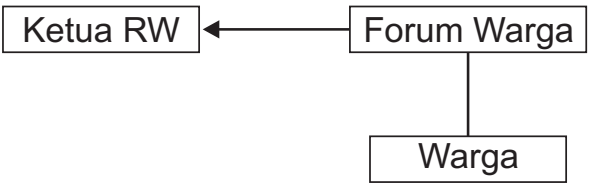

Gambar 11. Badan Eksekutif Efektif

Keterangan :

Forum warga memfasilitasi warga untuk aktif menyampaikan pendapatnya

Peran Ketua RW : koordinator pelaksanaan

Peran Forum warga : forum pendorong aspirasi warga

Peran Warga $\quad$ : forum pendorong aspirasi warga

(4) Desentralisasi Terbatas dalam Pengambilan Keputusan

Pada umumnya, desentralisasi terbatas diberikan pada user group/ kelompok pengguna untuk mempermudah pelaksanaan pelayanan dari pemerintah. Sedangkan pada lokasi penelitian, Kafilul Yatim sebagai organisasi sosial terbentuk untuk memberikan pelayanan/keringanan/bantuan

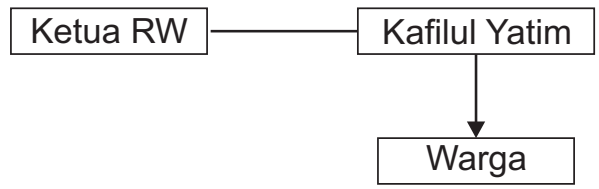

Gambar 12. Desentralisasi Terbatas

Keterangan :

Bukan berasal dari pelayanan (kelompok pengguna) tetapi ada untuk memberikan pelayanan/keringanan Peran Ketua RW : Penasehat

Peran Kafilul yatim : pemberi bantuan pada anak yatim dan kaum dhuafa

Peran Warga : : motor organisasi dan penerima manfaat adanya organisasi lokal

(5) Kemitraan

Kemitraan yang ada di lokasi penelitiam hanya sebatas kemitraan dengan sesama organisasi internal kampung. Jadi organisasi Kafilul Yatim terbentuk dari kemitraan antara anggota PKK dengan Karang Taruna, tak jarang pula Kafilul Yatim bekerja sama dengan pengurus langgar, perangkat RW, dan lain-lain.

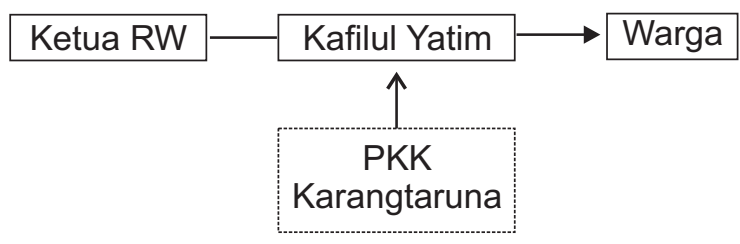

Gambar 13. Kemitraan

Keterangan :

a. Kafilul yatim terbentuk dari kemitraan yang dibangun oleh organisasi lokal

b. PKK dan Karang Taruna berperan sebagai anggota yang membantu pelaksanaan kegiatan 
(6) Kendali yang didelegasikan

Pada anak tangga kendali yang didelegasikan ini, tidak terjadi pada lokasi penelitian. dikarenakan tidak adanya organisasi lokal yang memiliki wewenang setara dengan pemerintah dalam melayani masyarakat umum aatu sama halnya pada pemerintah lokal melayani warga kampung. Jadi campur tangan pemerintah masih sangat kurang.

c. Derajat yang tertinggi adalah kendali warga (citizen control). Dalam derajat ini, warga memiliki kekuasaan untuk memerintah suatu program, wilayah, atau lembaga tertentu dengan derajat kemandirian yang kurang lebih sama dengan kemandirian pemerintah daerah

(1) Kendali yang Dipercayakan

Pada anak tangga kendali yang dipercayakan ini, juga tidak terjadi pada lokasi penelitian. Sebab memang peran pemerintah lokal tidak pernah memberikan bantuan keuangan ataupun kontrak pembantuan dalam mendirikan suatu organisasi kemasyarakatan.

(2) Interdependensi Kendali

Pada anak tangga yang tertinggi ini, seharusnya interdependensi kendali diberikan oleh pemerrintah lokal pada aparat kampung/ketua RW, tetapi pada kondisi yang sebenarnya, warga secara mandiri dapat menyelenggarakan sebuah PAUD dengan bantuan dari para donatur. Dengan tercapainya partisipasi pada tingkat ini diharapkan warga dapat mengembangkan kemandirian pada aspek penghidupan lainnya dengan lingkup yang lebih menyeluruh.

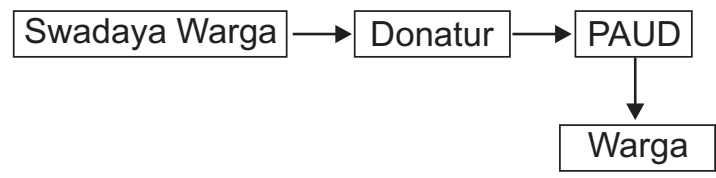

Gambar 14. Interpendensi Kendali
Keterangan :

PAUD terselengara berkat swadaya masyarakat sendiri dengan bantuan dari para donatur

Peran Donatur : pemberi dana/modal awal

Peran PAUD : lembaga pendidikan dengan biaya ringan

Peran Warga : penerima manfaat adanya PAUD

Berdasarkan hasil analisa di atas, maka dapat disimpulkan bahwa tingkat partisipasi warga Kampung Lorotan ada pada derajat yang kedua adalah partisipasi warga. Hal tersebut terlihat dari jumlah tangga partisipasi yang sesuai sebagian besar ada pada derajat partisipasi warga. Lokasi studi juga memiliki satu tangga yang berada pada derajat nonpartisipasi warga adalah tangga pemeliharaan pelanggan, tetapi tangga tersebut sudah tergolong sebagai pijakan yang baik dalam membangun sebuah tingkatan partisipasi yang lebih tinggi nantinya. Partisipasi warga yang ada di Kampung Lorotan juga sudah mencapai tingkatan yang tertinggi dalam derajat kendali warga, meskipun interdependensi kendali yang ada masih sangat terbatas pada lembaga Pendidikan Anak Usia Dini (PAUD). Untuk lebih jelasnya dapat dilihat pada Tabel 2.

Tabel 2. Kesimpulan Tingkat Partisipasi Kampung Lorotan

\begin{tabular}{|c|c|c|}
\hline $\begin{array}{c}\text { Derajat } \\
\text { Partisipasi }\end{array}$ & Tangga Partisipasi & $\begin{array}{c}\text { Karakter } \\
\text { Lokasi Studi }\end{array}$ \\
\hline \multirow[t]{2}{*}{$\begin{array}{l}\text { Kendali } \\
\text { warga }\end{array}$} & $\begin{array}{l}\text { 12. Interdependensi } \\
\text { kendali }\end{array}$ & $\sqrt{ }$ \\
\hline & $\begin{array}{l}\text { 11. Kendali yang diper- } \\
\text { cayakan }\end{array}$ & - \\
\hline \multirow[t]{6}{*}{$\begin{array}{l}\text { Partisipasi } \\
\text { Warga }\end{array}$} & $\begin{array}{l}\text { 10. Kendali yang } \\
\text { didelegasi }\end{array}$ & - \\
\hline & 9. Kemitraan & $\sqrt{ }$ \\
\hline & $\begin{array}{l}\text { 8. Desentralisasi secara } \\
\text { terbatas penganbilan } \\
\text { keputusan }\end{array}$ & $\sqrt{ }$ \\
\hline & $\begin{array}{l}\text { 7. Badan penasihat } \\
\text { yang efektif }\end{array}$ & $\sqrt{ }$ \\
\hline & 6. Konsultasi sejati & $\sqrt{ }$ \\
\hline & 5. Informasi berkualitas & $\sqrt{ }$ \\
\hline \multirow{4}{*}{$\begin{array}{l}\text { Non- } \\
\text { Partisipasi } \\
\text { Warga }\end{array}$} & 4. Pemeliharaan Pelanggan & $\sqrt{ }$ \\
\hline & 3. Informasi yang buruk & - \\
\hline & 2. Konsultasi yang sinis & - \\
\hline & 1. Penipuan warga & - \\
\hline
\end{tabular}

Sumber: Hasil analisa 


\section{SIMPULAN}

Bentukdan MotifPartisipasi Masyarakat. Hasil prosentase kecenderungan bentuk dan motif partisipasi menunjukkan bahwa bentuk partisipasi yang biasa dilakukan adalah sosial, tenaga, buah pikiran, dan harta benda. Hal tersebut menunjukkan bahwa pada lokasi studi, kemampuan partisipasi memang terbatas pada kesediaan warga dalam menghadiri rapat dan pelaksanaan kegiatan sebagai sarana untuk menjaga ikatan kemasyarakatan saja. Untuk motif partisipasi, warga lebih cenderung didasari oleh motif psikologi. Hal tersebut menunjukkan bahwa kesadaran warga Lorotan untuk berperan serta dalam setiap kegiatan cukup tinggi.

Kapasitas Organisasi Masyarakat. Pada konteks partisipasi sebagai upaya untuk menangani suatu permasalahan, organisasi lokal memiliki kapasitas dan relevansi yang tinggi jika dapat menampung partisipasi warga untuk mengambil keputusan. Berdasarkan hasil analisa kapasitas organisasi, ada tiga organisasi yang memiliki kapasitas tinggi adalah PKK, Karang Taruna, dan Forum Warga. Hanya Forum Warga memiliki alur pengambilan keputusan yang baik karena rutin mengadakan pertemuan dalam menentukan sebuah keputusan.

Tingkat Partisipasi Masyarakat Secara Keseluruhan. Secara keseluruhan, karakter lokasi studi sudah menunjukkan tingkat partisipasi pada derajat yang kedua adalah partisipasi warga. Hal yang menjadi nilai tambah dalam lokasi studi adalah warga mampu mencapai tingkat partisipasi yang tertinggi tanpa campur tangan pemerintah, dengan mendirikan secara swadaya PAUD Darul Jannah. Walaupun PAUD tersebut memiliki banyak keterbatasan, keberadaannya sudah dapat meringankan beban para warga.

\section{DAFTAR PUSTAKA}

Adi, F. 2011. Pemberdayaan, Partisipasi, dan Penguatan Kapasitas Masyarakat. Cetakan Kedua. Humaniora. Bandung.
Billah, MM. 1985. Alternatif Pola Pengembangan Partisipasi Rakyat. Makalah Majelis Dakwah Islamiyah.

Burns. D. Hambleton R., \& Hogget P. 1994. The Polities of Decentralization: Revitalising Local Democracy. London. The Mac Milan Press.

Carney, G., Dundon, T., Ni Leime, A. 2012. Participatory Action Research With and Within Community Activist Groups: Capturing The Collective Experience of Ireland's Community and Voluntary Pillar in Social Partnership. Action Research Queen's Belfast University 17: 313-330.

Erna, F.A. 2010. Design Action Research. Malang. Aditya Media Publishing.

Gedikli, B. 2009. The Role of Leadership in The Success of Participatory Planning Processes: Experience in Turkey. Journal European Urban and Regional Studies(16) 2: 115-130.

Ishak, K. 2009. Tingkat Partisipasi Masyarakat dan Dampak Program NUSSP. Jurnal Metropolitan (Vol. 7):516.

Kolopaking, L. M dan Fredian Tony. 2007. Pengembangan Masyarakat dan Kelembagaan Pembangunan: Tajuk Modul KPM-53C. Bogor. Departemen KPM dan Sekolah Pascasarjana IPB.

Lerner, J. 2013. Playing with Power: Participatory Planning Games in Rosario's Villas. American Planning Association (40) 2: 185-201.

Pasaribu, LL \& B. Simandjuntak. 1986. Sosiologi Pembangunan. Bandung.Tarsito.

Suparno, S.M. 2006. Perencanaan dan Pengembangan Perumahan. Yogyakarta. Andi Offset.

Yin, R.K. 1989. Case Study Research Design and Methods. California. Sage Publication. 